http://artnodes.uoc.edu

ARTICLE

NODE: "MEDIA ARCHAEOLOGY"

\title{
Crosscurrents in 'micro' marketing: home computers and media genealogy
}

\author{
Jörgen Skågeby \\ Stockholms Universitet Stockholm
}

Submission date: December 2017

Accepted date: April 2018

Published in: June 2018

\section{Recommended citation}

Skågeby, Jörgen. 2018. “Crosscurrents in 'micro' marketing: home computers and media genealogy". In Pau Alsina, Ana Rodríguez and Vanina Y. Hofman (coords.). "Media Archaeology". Artnodes. No. 21: 127-135. UOC [Accessed: dd/mm/yy] http://dx.doi.org/10.7238/a.v0i21.3176.

This article is - unless indicated otherwise - covered by the Creative Commons Spain Attribution 3.0
licence. You may copy, distribute, transmit and adapt the work, provided you attribute it (authorship,
journal name, publisher) in the manner specified by the author(s) or licensor(s). The full text of the
licence can be consulted here: http://creativecommons.org/licenses/by/3.0/es/deed.en.

\begin{abstract}
From the late 1970s to the mid 1980s, many countries experienced a "home computer boom". The "home computer" (or "micro" as it was colloquially referred to) had become a viable marketing concept because companies, having developed advanced and expensive machines for business, science and engineering applications, now identified a new market segment for more affordable, accessible, and less advanced single-user "home computers". The domestication of the computer is, naturally, an interesting phase in media history, revealing intermedialities, continuities, and disruptions in the development of digital culture. By analysing home computer marketing as it appears from 1981 to 1985 in magazine advertisements, this paper argues that we can come to a better understanding of the mutually transformative relation between the inherently technical design and language of software and hardware engineering and the ideological and cultural language of computerisation. The key research question for this paper is:
\end{abstract}




\section{artnodes}

http://artnodes.uoc.edu

Crosscurrents in 'micro' marketing...

How was the inherently technical language, and indeed material operations, of software and hardware engineering transcoded into marketing concepts? Or, in other words, how was human agency and technological agency negotiated through the visual language of marketing?

Answering this question will provide insights into how the impending computerisation of society started to take place at an ideological and semiotic level, which in turn is underpinned by the material capacities of media technologies. As a result, the paper identifies three tentative 'crosscurrents' where materialities, agencies and discourses are negotiated.

\section{Keywords}

home computers, micros, marketing, media genealogy, intended use, retrocomputing

\section{Contracorrientes en el márquetin del «microordenador»: ordenadores personales y genealogía de los medios}

\section{Resumen}

Desde finales de los setenta hasta mediados de los ochenta, numerosos países experimentaron el «boom de los ordenadores personales». El «ordenador personal» (0 «microordenador», como se denominaba coloquialmente) había pasado a ser un concepto viable de márquetin, puesto que las empresas, que habían desarrollado máquinas avanzadas y costosas para aplicaciones empresariales, científicas y de ingeniería, acababan de descubrir un nuevo segmento de mercado en los «ordenadores personales» para usuarios individuales, menos avanzados, pero más asequibles y accesibles. La domesticación del ordenador constituye, lógicamente, una fase interesante de la historia de los medios, que muestra intermedialidades, continuidades e interrupciones en la evolución de la cultura digital. Con su análisis del márquetin de los ordenadores personales tal como apareció entre 1981 y 1985 en anuncios de revistas, este artículo sostiene que podemos llegar a comprender mejor la relación de transformación mutua entre el diseño y el lenguaje intrínsecamente técnicos de la ingeniería de software y hardware y el lenguaje ideológico y cultural de la informatización. La pregunta principal de la investigación de este artículo es: ¿Cómo se transcodificó ese lenguaje intrínsecamente técnico, e incluso las operaciones concretas, de la ingeniería de software y hardware en conceptos propios del márquetin? 0, dicho de otro modo, ¿cómo se negoció, por un lado, la agencia humana y, por otro, la agencia tecnológica a través del lenguaje visual del marketing?

La respuesta a esta pregunta permitirá conocer mejor cómo empezó a producirse la inminente informatización de la sociedad desde un nivel ideológico y semiótico, que, a su vez, se ha visto respaldada por las propias capacidades materiales de las tecnologías de medios. Como resultado, el artículo detecta tres posibles "contracorrientes» en las que se negocian las materialidades, las agencias y los discursos.

\section{Palabras clave}

ordenadores personales, microordenadores, marketing, genealogía de medios, uso previsto, retroinformática 


\section{artnodes}

\section{Introduction}

During the early 1970s the public's understanding of computers was often rudimentary and coloured by pop-cultural images where computers were exciting, enigmatic and terrifying in equal measures. As Murrell puts it in his book on early home computers: "Despite the best efforts of engineers explaining their inventions, most people knew more about malevolent computers like HAL from Kubrick's film 2001 - A Space Odyssey, than the real thing." (Murrell 2013, 4). Nevertheless, less than a decade later the home computer was making its way into thousands and thousands of households. This paper will delve deeper into one of the general reasons behind this shift.

One of the most important reasons was of course that the development of home computer systems was followed by determined marketing and sales activities for these systems. As such, home computer systems, and the symbolism and language used to describe them, came to form a material-aesthetic-discursive relationship, where information came with both physical and philological propensities. This paper will argue that the marketing of the home computer played an important role in the development of digital culture, which is articulated with the emergence of certain aesthetics, visual regimes and temporal connections between established and emerging media technologies. This paper will thus analyse the combined aesthetics, ideologies and functionalities that permeated the marketing of home computer systems during the early 1980s. This will provide insights into how the impending computerisation of society has started to take place at an ideological and semiotic level, which in turn is connected to the material capacities of media technologies.

While there have been debates of whether marketing can be regarded as an art or a science (a debate into which this paper will not enter in depth), there are still reasons to examine marketing as form of negotiation in order to reveal the connections between material designs, cultural myths and discourses, and its combined diverse effects. In the case of home computers, it is also particularly interesting to examine how aesthetic elements are combined with and express underlying computational functionalities of the media technologies themselves. The fact that the target group was households naturally played an important part too. More specifically, the study will focus on revealing the underlying assumptions about what changes computerisation was predicted or intended to create based on the aesthetic presentation of the material capacities of software and hardware. Design comes in two variations here. Firstly, there is the design of the marketing material in itself. Secondly, the design of the computers, both in terms of their appearance, but also in terms of computational capacities.

By analysing home computer marketing as it appeared from 1981 to 1985 in magazine advertisements, we will come to a better understanding of the mutually transformative relation between the fundamentally technical design and language of software and hardware engineering and the ideological and cultural language of computerisation. Thus, the key research question can be stated as:

How was the inherently technical language, and indeed material operations, of software and hardware engineering transcoded into marketing concepts? Or, in other words, how were human agency and technological agency negotiated through the visual language of marketing?

Understanding how digital culture was sold to consumers during the bourgeoning ideological computerisation of society, can reveal not only continuities, but also dead ends - roots that withered and material-discursive machines whose media-and-discourse specificity left them in obscurity very soon after their release. Such 'market losers' have important stories to tell and temporal connections (to both contemporary, bygone and future digital culture) to explore (Huhtamo and Parikka 2011).

The paper begins with a brief survey of previous work including computer marketing, as well as studies of home computer adoption. The theoretical framework is then presented, identifying home computer marketing as a particularly interesting site of negotiation between human and machine. Next follows a thematic description of the conceptual crosscurrents identified in the material, which is, in turn, followed by a discussion of their implications for our practical and theoretical understanding of the media genealogy of home computers.

\section{Background and previous work}

The study of home computer marketing is as much a history of ideologies as one of computers and their capacities (Skågeby 2015). As Parikka argues: "we should complement technology-centered ideas with the wider imaginary and discursive histories and recognize how computers share elements with other media" (Parikka 2014, 249). When trying to convey the attraction and usefulness of computers to the household, the task for marketing and advertising was essentially to simplify and explain the programmability of computers and rationalise the place this functionality could have in the home (and, reversely, to adapt users to computer ontology). Inevitably however, when doing so, marketing also produced cultural perceptions of the interplay between human and machinic agencies (Goddard 2015) and thus conveyed perceptions of what potential uses the computer could be put to (Haddon and Skinner 1991).

Some work has been done on cultural perceptions of computers from a user perspective, much of which concerns gender stereotyping. For example, when examining cultural perceptions of computers from 1980 to 2007, partly through computer magazines, Corneliussen (2010) claims that the early 1980s were characterised by an open, 


\section{artnodes}

http://artnodes.uoc.edu

Crosscurrents in 'micro' marketing...

and sometimes even 'hospitable' perception of gender in relation to computers (which was to be followed by a strong masculinisation). In their study of computer advertising images, Tympas et al (2010) support this view, stating that computing had a strong link to nonmasculine attributes, but at the same time, suffered from very stereotypical representations, which, according to the authors, were consequential in shaping the (subsequent) public image of computing.

Of interest is also the adoption patterns of home computers, as they give us some idea of who actually went ahead and purchased the machines. In an early study, Dickerson and Gentry (1983) contrast adopters and non-adopters finding that previous computer experience was important for adoption. They also present a 'psychographic' profile of the adopter, suggesting the s/he is a "logical introvert" (introverted, rational, quantitatively oriented, unsocial, uninterested in the arts), who can recognise the compatibility of computing and the home. In another study, McQuarrie (1989) follows up on adoption, conceptualising the events that follow a purchase of a home computer (i.e. degree of usage, satisfaction and attitude toward the technology). The results of the study go against the results produced by Dickerson and Gentry, and instead indicate that 'product strength' (amount of hardware and software owned; manufacturer support) and social integration (social interaction involving computers) were the aspects most positively related to higher usage, satisfaction and attitude. In other words, people who had good equipment and a social network around computing were the happiest adopters of home computers. In an intriguing account of the underpinning masculinisation of home computers, Haddon (1990) defines three phases in their conceptualisation and adoption. Firstly, three existing communities were quick to take up home computers: science/maths teachers, computer professionals and electronics hobbyists. Moving on from these slightly restricted hobbyist early adopters, the home computer became more of a mainstream consumer appliance. In its final phase, the home computer was marketed primarily as a gaming machine. As we shall see, these three phases are also reflected in marketing, but as this paper will argue, they are reflected not so much as distinctive phases, but as crosscurrents - sometimes running in parallel, sometimes intersecting, sometimes counter-flowing. Even more interestingly, these crosscurrents also turn into subterranean streams, networking with other underground streams and resurfacing at other points in time and space. ${ }^{1}$ As Haddon and Skinner argue elsewhere: "In practice, the micro has been and remains a constantly changing product: changing as a technology, changing in terms of how it is understood by the culture in which it is situated, and changing in the way that it is perceived and used by individuals" (Haddon and Skinner 1991, 435).

As can be seen from the survey, a significant amount of work has been done on the adoption of the home computer, and some work has been done on home computer advertisements and gender representation. It seems, however, that a combined reading of human and machinic agencies and how they are articulated and coordinated in home computer marketing is still lacking.

\section{Theory and method}

In his paper on the operating system, Ellis poses two possible questions for media archaeological inquiry: "Faced with an unfamiliar machine, do we ask 'how was it used?' or 'what can it do?' Very different archaeologies flow from these two questions" (Ellis 2015, S24). As this paper argues, yet another possible archaeological flow is located in-between these queries, namely "how was it intended to be used?" This question partly takes into account both what a machine can do and how it was used. As we know, intended use and actual use can differ greatly. Nevertheless, this paper argues that an examination of intended use (as expressed in marketing) is not rendered meaningless by auxiliary actual use practices, but remains a necessary facet for tackling the full media genealogy of home computers (and other media technologies).

As mentioned, this paper argues that the home computer is a nexus of intermedialities, continuities and disruptions between the 'new' and the 'old'. But also, as a marketed commodity, the home computer is as much a social product as it is a technical one; in many ways a "compromise between engineers and salespeople", as Kittler expresses it in Gramophone, Film, Typewriter (Kittler 1999, 2), referring to the negotiations between the material and the marketable. New media theorist Lev Manovich expresses this in a parallel fashion, stating that there is a mutual influence between a cultural layer and a computer layer. This mutual influence is referred to by Manovich as a process of transcoding. According to Manovich, transcoding is a form of co-interpretation, where the "cultural layer" is interpreted in terms of computer ontology and the "computer layer" is interpreted in human cultural terms. Manovich suggests that these layers are not easily separable - especially seeing how so much of our "cultural" information is now stored and processed by computers. Manovich tends to stress how the increasing digitalization of cultural information subjects culture at large to the ontology of the computer. But he also maintains that this influence is not unidirectional - software and hardware is created by culture as much as it creates culture.

This means that we should pay as much attention to cultural history as to the computer's unique possibilities to generate, organise, manipulate and distribute data. So, software studies and studies into the cultural history of computers must not only investigate the ways in

1. As with natural rivers, media-technological crosscurrents may be more or less diverted underground or 'daylighted' through, for example, political decisions, intermedial connections, design intentions or nostalgic user practices. 


\section{artnodes}

http://artnodes.uoc.edu

Crosscurrents in 'micro' marketing...

which the computer's ontology shapes culture, they must also analyse the culture that shapes computer programming and computer use and, as this chapter will argue, the double design of computer marketing.

To rehash, Manovich asserts that transcoding is the process by which cultural information is transformed into computer code, but also a process where computer ontology transforms into cultural terms. Manovich effectively expresses it like this:

The result of this composite is the new computer culture: a blend of human and computer meanings, of traditional ways human culture modelled the world and computer's own ways to represent it. (Manovich 2001, 64)

As mentioned, this chapter will argue that marketing and advertising hold a particularly interesting position in this transcoding process, especially seeing how they arguably try to sell computer ontology to the public through a culturally specific and very ideologically charged aesthetic. As such, this paper takes a more media-genealogical approach to conducting "an explicit analysis of the visible surface of contesting forces and power relations on which archaeological depth is laid out" (Monea and Packer 2016, 3152). While the present study can, by no means, claim to cover an entire materialdiscursive infrastructure, it supports the view that an "[...] analysis of technology requires an examination of the discourse through which that technology has been produced as an object of knowledge for thought" (Monea and Packer 2016, 3153), and marketing is part of such a knowledge-and-ideology-producing discourse network. So, while this paper does not go into how computers were used in, or transformed, the actual production of marketing, it does investigate the transcoding process between the cultural reception of the home computer and its material functionality.

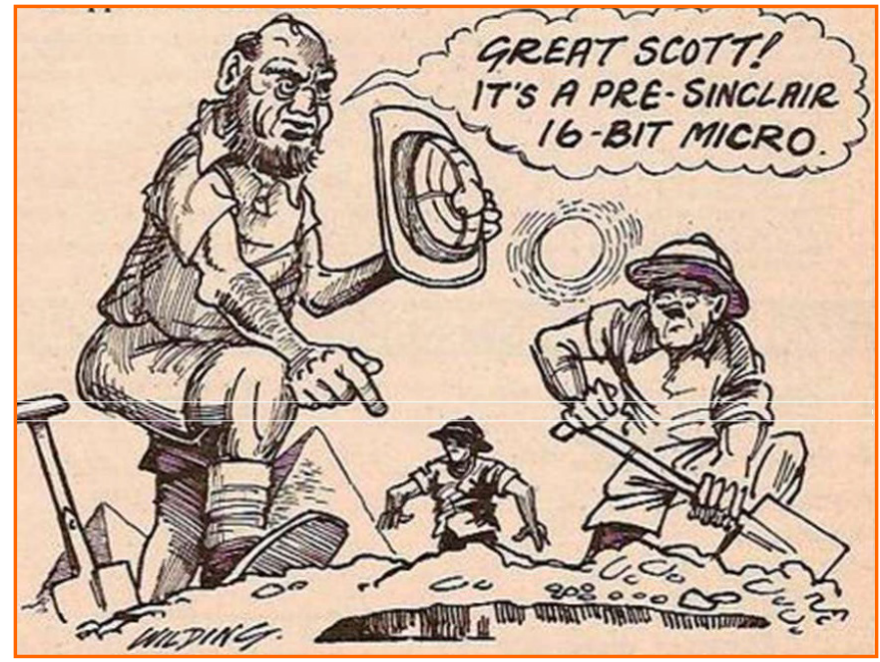

Image 1. Cartoon referring to concrete media archaeology, also using the colloquial term 'micro' (short for microcomputer). Your Computer magazine, October 1985
For this short paper, British home computer magazine Your Computer was selected on the basis of its popularity (in its own words, it is "Britain's biggest selling home computer magazine") and its inclusive approach to home computers of all brands. Your Computer was launched in 1981 and published monthly issues up until 1988. From the years 1981 to 1985 approximately, the magazine reflected the exuberant home computer market, with lots of minor and major brands represented. Arguably, from 1986 to 1988, the home computer was increasingly converging into the 'personal computer' (PC) with an equally converging range of brands. As such, this paper will focus on the years 1981 to 1985 . To limit the material for this pilot study, a month was selected randomly (October) and the annual issue for that month was included in the empirical material, resulting in 5 magazine issues. After initial screening, leaving out adverts smaller than a page, 78 examples remained for analysis.

\section{Crosscurrents in home computer marketing}

The results of this study consist of conceptual connections revealing how the impending computerisation of society took place at a combined material and ideological level during a period when the domestication of the computer was widespread. These conceptual connections are illustrated through what this paper refers to as 'crosscurrents'. Fornäs (2008) describes crosscurrents as a form of analytical dimension with two counterpart streams: "[...] they form double streams that may run in parallel, feed into each other, or become crosscurrents whose intersections create tensions and contradictions. Each pair is in some sense paradoxical and contradictory, pointing out key ambivalences and contradictions in the present situation. This is therefore an alternative to thinking in terms of gaps or borders" (Fornäs 2008, 895).

Admittedly, as the study is based on limited material, the crosscurrents presented below can only represent preliminary observations that have been made. A widened study would probably reveal additional crosscurrents present in home computer marketing. Nevertheless, the currently identified crosscurrents are manifest in the selected material, and in a way that is contradictory but also parallel, so too are trends that run throughout home computer advertising in the early 1980s.

\section{Transparent machines and black boxes}

The first key crosscurrent is between the transparent machine and the black-boxed appliance. On a cultural level, this relates to the tension between 'hobbyists' and casual users. The hobbyist is someone who wants to learn about computers in themselves - either by assembling components in order to understand the electronic 


\section{artnodes}

http://artnodes.uoc.edu

Crosscurrents in 'micro' marketing...

basis of the computer, or by programming and learning the code that computers run by. Haddon and Skinner refer to this as 'self-referential' use (Haddon and Skinner 1991). Marketing aimed at the hobbyist concentrates on modular hardware, various construction kits and coding. Rarely are there any wider purposes expressed to the use/ assembly of this hardware, rather the ads are targeted towards users who are interested in hardware in itself. Consequently, the hobbyist also connects to a previous step in this media genealogical route, namely the electronics enthusiast, whose interest lies in making/ building and learning about (combinations of) electronic components in themselves. Connecting to the media archaeological ideas of Goddard (2015) and Hertz and Parikka (2012), this is clearly a case of gaining transparency into black boxes. That is, of going inside the machine and tinkering with the capacities of the physical medium itself. The casual user on the other hand is conceptualised as anyone, or particularly in the case of home computers, as anyone in the family. The marketing efforts change both aesthetically and in terms of the computational functionality that is emphasised. The anticipated and suggested uses that are relevant for casual users are such things as managing the household accounts, learning about the solar system or storing cookery recipes - all clearly related to already existing household chores (e.g. home economy, homework, home cooking), indicating how the home computer was marketed as an addition to already existing household appliances.

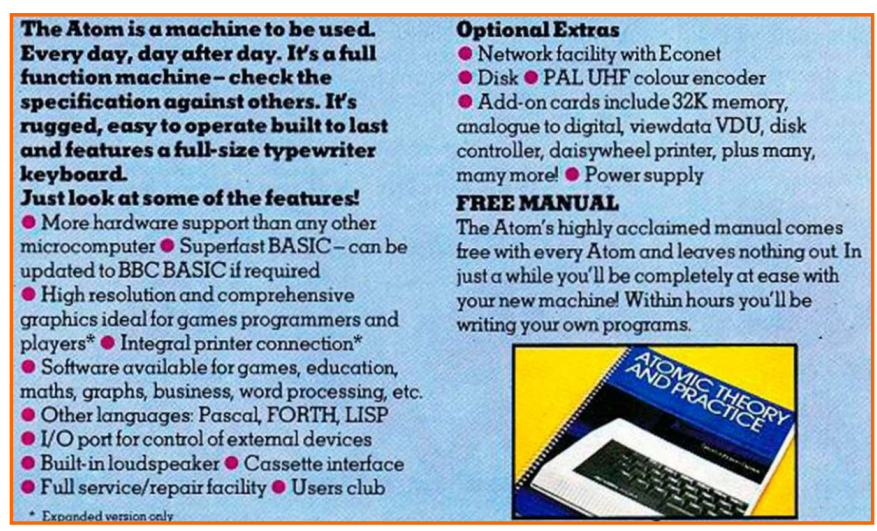

Image 2. Excerpt from an ad for the Acorn Atom, stressing hardware capacities but also the range of programming languages available (and completely leaving out any cultural uses) (Your Computer, October 1981).

What is also interesting about this crosscurrent is that marketing is not entirely convincing in terms of what is new about the computer (at least for casual users). Rather it seems its selling point is that it converges previously separate cultural layer activities into one machine. At the same time, each brand is also specific in its improved hardware and software setup (the computer layer). So, when moving from a transparent machine to a black-boxed appliance, advertising is trying to make the home computer relevant for everyone, but at the same time its relies heavily on previous household chores. This results in a mix of a remediation logic, which focuses on the cultural layer and the all the activities you used to perform without a computer that you can now do with the computer - and media specificity, which stresses the computational layer and the various specific and superior hardware capacities that can now be afforded for the least amount of money. In summary, on the one hand, this crosscurrent stresses transparency, hardware and media-specificity (hobbyists); and on the other hand, black-boxing, pre-made software and remediation of existing cultural activities (casual users).

An example of something that exists as a whirlpool in this crosscurrent is programming. While programming is certainly an abstraction from the physical layer of the computer, it also allows for some transparency into the capacities of the specific machine. Home computer magazines at this time were, of course, also full of program listings, with pages and pages of code to be entered (and potentially modified) by users themselves. Over time, programming was also transformed from something 'self-referential' (see above) to something that could be of interest to a wider range of users. In particular, children and teens were put forward as a group that should learn how to program computers in order to not lag behind (tapping into concerned parents' well-wishes). Notably, there was (in a similar fashion to VHS and Betamax in the video home recording market) something of a war going on, not only between different computer brands and their specific (choice of) hardware standards, but also in terms of programming languages.

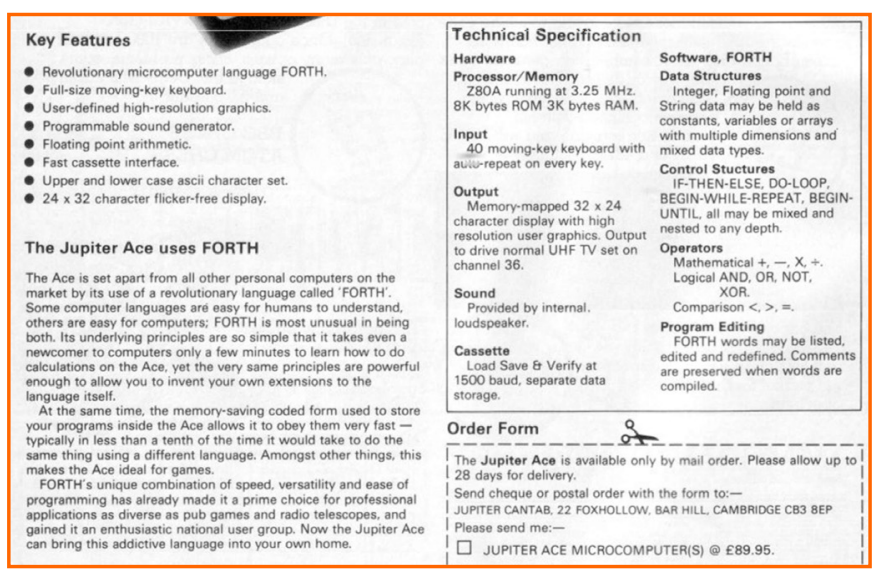

Image 3. Excerpt from a Jupiter Ace advertisement (Your Computer, October 1982)

The picture above is taken from an ad for the Jupiter Ace computer. This particular home computer used FORTH, instead of the more common BASIC, as its primary programming language. Even though FORTH was arguably a better, more structured and memory-efficient programming language (even allowing recursive programming), it did not reach the popularity of BASIC, which remained the go-to (pun intended) language for most home computer owners. 


\section{artnodes}

http://artnodes.uoc.edu

Crosscurrents in 'micro' marketing...

Just from looking at how home computer marketing developed during the early 1980s, it becomes clear that more and more cultural layer concepts were introduced into what was still a technically oriented lingo - from specific application areas, such as games and education, to broader (computer-)culturally oriented notions, such as usability, communication, creativity and even computer-supported dating and marriage counselling.
The list of top quality software for the Acorn Electron is growing all the time.

As you can see, therés already an outstanding selection of exciting programs covering everything from monsters to music and murder to marriage guidance.

And ultimately, the Electron will enjoy a range of software as comprehensive as that of its illustrious big brother, the muchacclaimed BBC Micro.
GRAPHICS: Craphs \& Charts, Creative Graphics, Picture Maker. BUSINESS: Personal Money EDUCATION:'Iree of

Knowledge, Peeko-Computer, Business Games. LANGLAGES: LISP,FORTH, S-Pascal, Turtle Graphics. GAMFs: Starship Command, Monsters, Chess, Draughts and Reversi, Snapper, Meteors, Hopper, Sphinx Adventure, Arcadians, Free Fall.
Management, Desk Diary.

Image 4. Excerpt from an Acorn Electron advertisement (Your Computer, October 1984)

\section{Peripherals and central units}

A crosscurrent related to that of transparent machines and black boxes is the crosscurrent of peripherals and central units. By peripherals, I here refer to extra equipment used to expand the computer and its capacities in different ways (e.g. printers, 'expander boxes', replacement CPUs, bus extenders, special monitors, analog/digital converters). This is also a sign of the latent tension between the computer layer and the cultural layer. That is, it becomes evident that the continuous introduction of new peripherals reflected the expanded imagined cultural uses of the computer. The marketing of networking interfaces, printers, gaming equipment and musicmaking kits attempted to convey the newly found cultural uses of the core machine, which could, potentially, also enhance its perceived usefulness as a household appliance, attracting users to acquire and/or expand an (existing) computer system. The capacity of the machine was in direct relation to the potential agency of the use. Today, the situation is, in some ways, reversed. We often buy machines with capacities far beyond our needs, and a single smartphone has converged a multitude of functionalities, previously supported by peripherals, into one single device. In terms of agency, it could also be argued that intentional and unintentional design choices are, to a much higher degree, both extending and limiting our abilities to act today.

The picture above illustrates this crosscurrent between a more modular system, where a computer is gradually expanded with peripheral equipment (the TRS-80, and clones, had a particularly

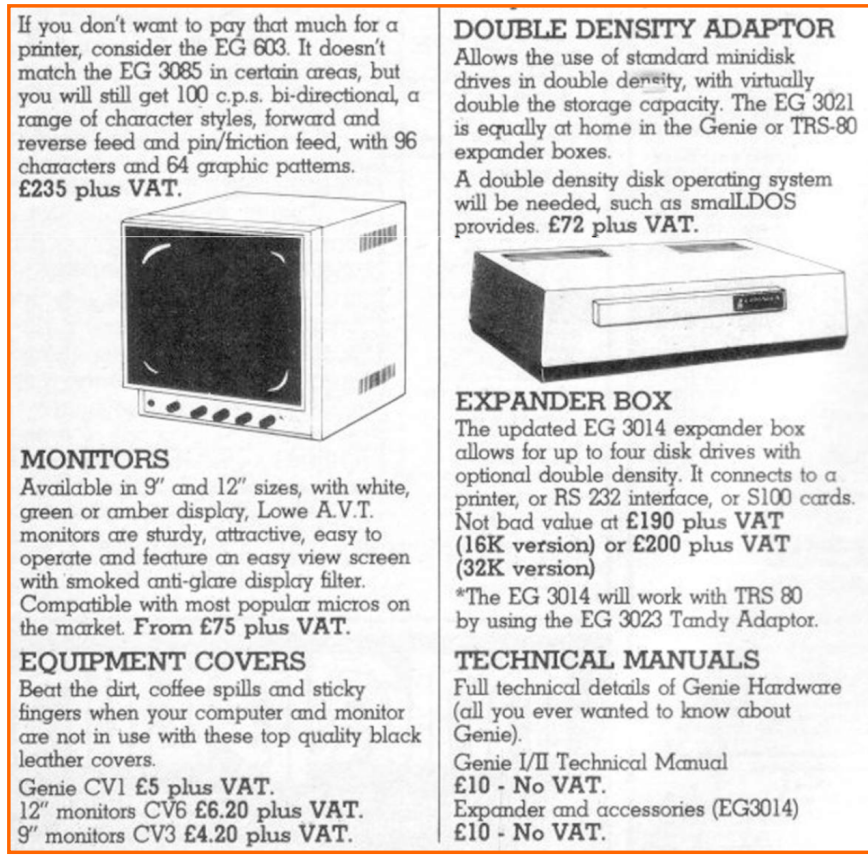

Image 5. Excerpt from a two-page advert selling mainly peripherals for the Hong Kong manufactured Tandy TRS-80 clone (Video) Genie I and II. (Your Computer, October 1982)

extensive line of upgrades), and a complete, ready-to use 'starter pack'. Interestingly, the ad above also refers to a so-called 'clone' computer, in this case a clone of the Tandy TRS-80. A clone is simply a hardware (or software) system designed to function in the same way as an existing system, and was quite common during the heyday of home computers.

\section{Storage and cataloguing}

Kirschenbaum (2012) has convincingly argued that understanding the affordances (or forensic materiality) of storage devices is essential to understanding digital media. While the readings conducted in this paper will not go into detail about the physical or the logical level of the media technologies presented in the empirical material, these levels have to be recognised and acknowledged when considering the conceptual level of use. For example, many home computer ads stress the storage capacities of computers by trying to relate this to what is commonly stored in the household. Consider for example this excerpt from an ad for the Sinclair Spectrum ZX81:

Finances, friends, diaries, recipes and hobby-related collections are amongst the suggested uses for 'cataloguing' via digital storage.

What was not stressed was of course the underlying computer layer, which would require significant data entry, as well as the issue of information retrieval becoming obsolete very quickly (i.e. the data 


\section{artnodes}

http://artnodes.uoc.edu

Crosscurrents in 'micro' marketing...

not being portable, or new hardware not being compatible, within a few years). In combination, the computer layer and the cultural layer would generate a tedious, and ultimately superfluous, amount of effort if the user were to take advantage of the suggested usefulness of computer storage.

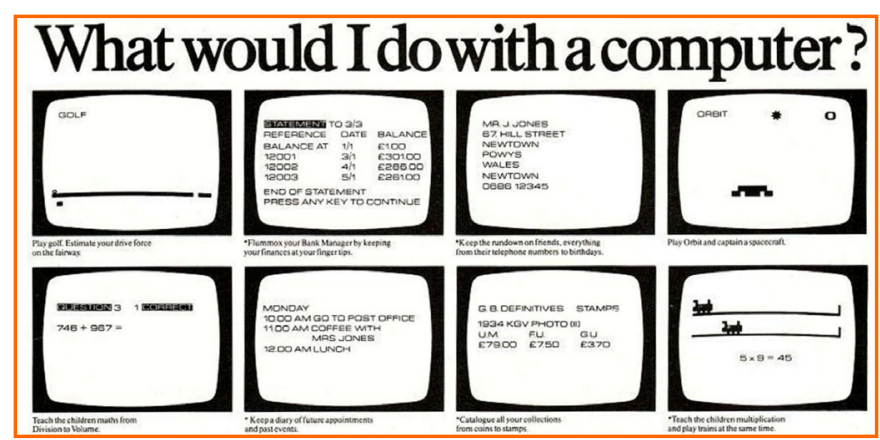

Image 6. What would I do with a computer? (Your Computer, October 1981)

\section{Discussion and conclusion}

This paper has presented a conceptual framework, including media genealogy, intended use, transcoding, and crosscurrents, and applied it to a small body of home computer marketing material. As such, in its brief exposé, this paper has identified three tentative media genealogical crosscurrents in home computer marketing, each reflecting the interplay between a 'computer layer' and a 'cultural layer'. The three crosscurrents are: transparent machines and black boxes; peripherals and cores; and storage and cataloguing. Not only do these three crosscurrents indicate tensions between computing and culture in themselves; when compared to each other there is also an indication that, while a heavy emphasis was placed on the computer layer in early marketing, a more balanced equilibrium with the cultural layer was soon expressed. Still, it is striking how marketing was both very uncertain about the cultural uses, but nevertheless also very determined that 'this was the future' (which it would, by all accounts, also be).

Apart from taking a broader and deeper look at home computer marketing in terms of empirical scope, there is also another aspect of future research to be considered. Elsaesser (2016) points to the fact that one of media archaeology's objectives has been to 'think a different kind of future'. This ambition becomes interesting when looking at home computers. In one way, the future of the home computer is already written - our homes are now filled with computers. While many intended uses never really caught on (or were adopted much later, once computing capacities had caught up with cultural desires), the subterranean flow of the home computer has, in some ways, resurfaced. Apart from the crosscurrents present in 1981-1985 marketing, there is thus reason to address yet another crosscurrent, with more contemporary nuances: the one between nostalgic recollection and forward-looking projection. That is, home computers are today experiencing something of a revival, with lots of people seeking new access to old memories (through old media technologies). This has spurred a bourgeoning retrocomputing culture (and accompanying second-hand market) where old machinery is revived and used in nostalgic ways, but also to create progressive cultural artefacts relying on media-specific aesthetics. In contemporary digital culture, this practice has to be seen as comparatively lo-fi, and not so much as a case of home computers "surviving as ornament and luxury accessory", as Elsaesser said about cinema (Elsaesser 2016, 196). Instead, the retrocomputing phenomenon can be seen as a form of residual media culture (Acland 2007), but perhaps even more so, as a zombie media culture (Hertz and Parikka 2012) where a practically obsolete and culturally obscured stream of technology has resurfaced for new purposes in contemporary digital culture. As such, studies of these contemporary (re-)uses of old computers clearly have echoes of media archaeological ambitions; to trace the many multiplying roots of digital culture through a combination of machinic close-readings and the textual, visual and auditory archives that media technologies both are and have produced and generated around them. For future research, it would thus be important to examine the question of 'what are obsolete home computers (good) for today?' Are they just another part of "our culture's most prominent pathology: the need to preserve the past, to fetishize 'memory' and 'materiality' in the form of trauma and loss, even as we lose faith in history and make our lives evermore dependent on the 'virtual' (Elsaesser 2016, 206) or is there something more? As new generations are introduced to old home computers (by parents and friends); as recurring retrogatherings and convents are attracting more and more visitors; as everyday-expert methods for data preservation and forensics are developing; and as amateur archives of forgotten computer culture are growing, I think the answer to this question is that there is definitely something more to these practices than fetishization and nostalgia, and that contemporary retrocomputing studies will be able to reveal much about the transcoding between the materiality of computing and the cultural importance of 'obsolete' machines.

\section{References}

Acland, C. R. (ed.). 2007. Residual Media. Minneapolis, MN: University of Minnesota Press.

Corneliussen, H. G. 2010. "Cultural Perceptions of Computers in Norway 1980-2007". In T. J. Misa (ed.). Gender Codes: Why Women are Leaving Computing. Hoboken, NJ: John Wiley \& Sons Inc. https://doi.org/10.1002/9780470619926.ch8

Dickerson, M. D. andJ. W. Gentry. 1983. "Characteristics of Adopters and Non-Adopters of Home Computers". Journal of Consumer Research, 10(2): 225-235. https://doi.org/10.1086/208961. 


\section{artnodes}

http://artnodes.uoc.edu

Crosscurrents in 'micro' marketing...

Ellis, J. 2015. "Between Human and Machine: The Operating System". Journal of Contemporary Archaeology, vol. 2, no. 1:24-28. https:// doi.org/10.1558/jca.v2i1.28283

Elsaesser, T. 2016. "Media archaeology as symptom". New Review of Film and Television Studies, vol. 14, no. 2: 181-215. https:// doi.org/10.1080/17400309.2016.1146858.

Fornäs, J. 2008. "Bridging gaps: ten crosscurrents in media studies". Media, Culture \& Society, vol. 30, no. 6: 895-905. https://doi. org/10.1177/0163443708096811.

Goddard, M. 2015. "Opening up the black boxes: Media archaeology, 'anarchaeology' and media materiality". New Media \& Society, vol. 17, no. 11: 1761-1776. https://doi. org/10.1177/1461444814532193.

Haddon, L. 1990. "Researching gender and home computers". In K. Sørensen and A. Berg (eds.). Technology and Everyday Life: Trajectories and Transformations. Trondheim, Norway: University of Trondheim.

Haddon, L. and D. Skinner .1991. "The Enigma of the Micro: Lessons from the British Home Computer Boom". Social Science Computer Review, vol. 9, no. 3: 435-449. https://doi.org/10.1177 /089443939100900305.

Hertz, G. and J. Parikka. 2012. "Zombie Media: Circuit Bending Media Archaeology into an Art Method”. Leonardo, vol. 45, no. 5: 424430. https://doi.org/10.1162/LEON_a_00438.

Huhtamo, E. and J.Parikka. 2011. "Introduction: An Archaeology of Media Archaeology". In E. Huhtamo and J. Parikka (eds.).
Media Archaeology: Approaches, Applications, and Implications. Berkeley, CA: University of California Press.

Kirschenbaum, M. G. 2012. Mechanisms: New Media and the Forensic Imagination. Cambridge, MA: MIT Press.

Kittler, F. A. 1999. Gramophone, Film, Typewriter (G. Winthrop-Young \& M. Wutz, Trans.). Stanford, CA: Stanford University Press.

Manovich, L. 2001. The Language of New Media. Cambridge: MIT Press.

McQuarrie, E. F. 1989. "The impact of a discontinuous innovation: Outcomes experienced by owners of home computers". Computers in Human Behavior, vol. 5, no. 4: 227-240. https:// doi.org/10.1016/0747-5632(89)90002-2.

Monea, A. and J. Packer (2016). "Media Genealogy and the Politics of Archaeology". International Journal of Communication, no. 10: 3141-3159.

Murrell, K. 2013. Early Home Computers. Oxford: Shire Publications.

Parikka, J. 2014. "History of Computers". In M.L. Ryan, L. Emerson and B. J. Robertson (eds.). The Johns Hopkins Guide to Digital Media: 249-254. Baltimore: Johns Hopkins University Press.

Skågeby, J. (2015). Engineering meets marketing: advertising softand hardware in the 1980s. Paper presented at In the Flow: People, Media, Materialities, Norrköping.

Tympas,A.;H. Konsta;T.LekkasandS.Karas(2010)."Constructing Gender and Technology in Advertising images". In T. J. Misa (ed.). Gender Codes: Why Women are Leaving Computing. Hoboken, NJ: John Wiley \& Sons Inc. https://doi.org/10.1002/9780470619926.ch9.

\section{CV}

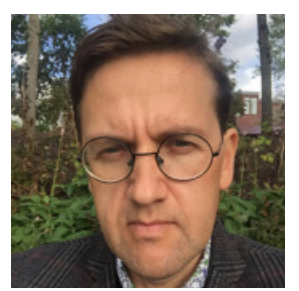

\section{Jörgen Skågeby}

Stockholms Universitet Stockholm

jorgen.skageby@ims.su.se

Department of Media Studies, Stockholm University

JMK, Box 27 861, 11593 STOCKHOLM, Sweden

Jörgen Skågeby is an associate professor at the Department for Media Studies at Stockholm University, Sweden. His research interests include the media archaeology of home computing, design fiction and humanistic $\mathrm{HCl}$. 